\title{
Building Blocks for Chinese SMEs to Enter the Global Market: The Roles of Upstream Knowledge and Downstream Channel Infrastructure
}

\author{
Yong Cao (Corresponding author) \\ College of Business and Public Policy, University of Alaska Anchorage \\ Anchorage, AK 99508, USA \\ Tel: 1-907-786-4176_E-mail: afyc@uaa.alaska.edu \\ Daniel Hartung \\ College of Business and Public Policy, University of Alaska Anchorage \\ Anchorage, AK 99508, USA \\ Edward Forrest \\ College of Business and Public Policy, University of Alaska Anchorage \\ Anchorage, AK 99508, USA \\ Zhengping Shen \\ College of Urban and Environmental Studies, Xuzhou Normal University \\ Xuzhou, Jiangsu Province, China
}

Received: December 9, $2010 \quad$ Accepted: February 10, $2011 \quad$ doi:10.5539/ijbm.v6n7p77

This project was completed while Dr. Yong Cao was a visiting professor in China Xuzhou Normal University in summer 2010. Dr. Shen's research was supported by National Natural Science Foundation of China (40971081)

\begin{abstract}
Small and medium enterprises (SMEs) are the most important economic components in China's economy- in that they account for 98.9 percent of the total number of businesses and 65.6 percent of China' $\mathrm{s}$ industrial output value. Chinese SMEs have forestalled rapid expansion into global markets due to the constraints of language, culture, and logistics. This paper examines Chinese SMEs limitations in addressing these constraints. Three contingency strategies (niche market strategy, strategic networking and e-commerce) are proffered to assist China's SMEs to more fully compete and succeed in their international efforts.

Keywords: Small and medium enterprises, Constraints in global market, Contingency strategies, Niche market, Networking, E-commerce

\section{Introduction}

Small and medium enterprises (SMEs) are the most important economic components in the global economy because SMES contributed 80 percent economic growth worldwide (Jutla et al., 2002). SMEs are particularly important in China, because current SMEs account for 98.9 percent of the total number of businesses and 65.6 percent of industrial output value in China (Singh, Garg and Deshmukh 2010). However, Chinese SMEs only contribute 40 percent share of the manufactured exports, which indicates that there is a strong potential for Chinese SMEs in the global market. Given the significant role that SME's have played in China's economic growth and the millions of SME's that have not yet entered the global market, it is prudent to consider the key constraints that PRC SMEs face when considering entering the global market.

Decisions on foreign market selection and mode of entry significantly affect a SME's performance. For any business that contemplates or initiates entry into the global market, expertise in language, culture, and logistics is imperative. Without sufficient expertise within and across these domains, successful entry into global markets is certainly improbable, if not impossible.
\end{abstract}

This paper will address the roles of language, culture, and logistics for the People's Republic of China's (PRC) 
small and medium enterprises (SMEs) participation in Global markets. These three fundamental constraints effectively prevent many PRC SMEs from entering and participating in global markets. Several strategies are identified that can assist and encourage China's SMEs to acquire and build their capacity to engage in the global market.

\section{Literature Review}

Due to the increasing importance of Chinese SMEs in China's economy and their presence in the global market, more academic studies are focusing on the issues of Chinese SMEs. Currently, most studies focus on the performance measures and factors that influence their performances. For example, Ren (2003) evaluates Chinese SMEs' competitiveness based on the systems of survival capability, growing capability, and development capacity. Similarly, Zhang and Hang (2007) investigate SME's sustainable development based on a number of financial indicators, such as profitability, asset managerial ability et al.

Many SMEs in China are family-based businesses, and the founders did not possess management skills or financial expertise, which may limit firm's further development in the future (Chen 2006). Similarly, Hussain et al. (2006) found that most Chinese SMEs have limited growth potential due to their financial constraints. China adopted a more proactive policy to support the development of SMEs (Hussain et al., 2006) by implementing the SMEs Promotion Law with an objective to remove institutional barriers, encourage innovations, and increase the competitiveness of SMEs (Chen, 2006). While above studies uncover some unique features of Chinese SMEs, very few studies are directly related to the SMEs' global performance and the key factors inhibiting their further development.

The other stream of study is related to firm's internationalization process. For example, exporting is the first stage of internationalization of small firms (Jones, 2001). During its internationalization process, most firms possess unique advantages, such as superior technology, unique products or marketing know-how (Chen \& Chen, 1998). However, due to their limited size and resources, many small firms tend to have limited international exposure because they do not have enough motivation and mechanisms for internationalization (Wright, Westhead, \& Ucbasaran, 2007). The most recent studies demonstrate that global social networks have important roles on internationalization of firms in Asia (Chung, 2006; Lee, Lee, \& Pennings, 2001; Zhou, Wu, \& Luo, 2007). Social networks can effectively reduce the language and cultural barriers for firms to expand business to the global markets.

This paper offers contributions to international business studies by providing a conceptual framework of key factors inhibiting Chinese SMEs' global expansion. In addition, a set of solutions is also provided as a contingency strategy to resolve such inhibiting factors. Our framework is consistent with recent studies that show strategic networking may be the key to reducing the language and cultural barriers for Chinese SMEs through hiring more returning entrepreneurs to build networks with oversea firms (Tung \& van Witteloostuijn, 2008). Our study helps Chinese SMEs find efficient ways to resolve potential conflicts due to language, culture and logistic barriers.

\section{Constraints for Chinese SMEs in Global Market}

PRC SMEs' participation in global markets has evolved as China has transitioned from a centrally-planned economy to a market economy. The SME sector in the PRC was officially allowed on the fringe of the economy after 1979. Albeit, the most significant impact on the SMEs structure and growth has occurred over the past 20 years- since China joined the World Trade Organization (WTO) in 2001. China's market is more open to foreign companies, which has simultaneously increased competition in the domestic market. Ultimately, Chinese firms were encouraged to consider global markets. During the same time, foreign firms began to play an important role in modernizing many SMEs by integrating them into the global value chain system. The prevalence and prominence of SMEs could be traced to three sources: governmental, social, and economic reforms carried out in both rural and urban areas; a large and expanding consumer demand following liberalized social and economic governance. Finally, the development has been encouraged by governmental support for a free market institutions and processes.

Given the vital role of the SMEs in increasing the nation's exports and global market revenues, it is not surprising that in 2010 China announced policies to enhance support for SMEs with preferential tax policy and easier channels to raise funds. Enticements for SMEs to enter global markets are driven by the economic benefits resulting from participation within wider markets and potential increased sales. At the current stage, most Chinese SMEs are focusing their sales to the domestic or global retailers with no leverage on pricing and other negotiation power. Consequently, these firms are trapped in the role of weak chain member controlled by the giant supply chain captains, such as Wal-Mart or other retailers. Very few Chinese SMEs can now effectively enter and compete on a global scale.

Any analytic framework that deals with SMEs in the PRC must address two primary areas: knowledge of the market and access to the market. The former is upstream, and focuses on the ability of SMEs to understand and enter the market; while the latter is downstream, and is concerned with entry, participation, and competing within markets. These two areas are the building blocks for Chinese SMEs to be success in the global market. 
Entering and prospering in new markets is always a challenge. SMEs often lack the resources to hire in-house staff with relevant expertise in the three critical domains that must be addressed for successful market expansion: language, culture and logistics. Language and culture are the major elements of knowledge of the market and are the keys for Chinese SMEs to access to the global market.

\subsection{Language}

One language is different from other languages in vocabulary, grammar, written form, syntax and a myriad of other characteristics (Chiswick and Miller 2004). Language reflects expressions of perceptions, conceptions, desires, actions, time, attitudes to action, structures and procedures for commerce, and how these are used in business activities. Without a mastery of local language, a person cannot express her knowledge to others. A commonly shared language is the key to maintain epistemological belief for people from different tribes $(\mathrm{Du}$ Toit, 2003). In this sense, language knowledge is important for global marketers.

One common way to address the distance between languages is to measure how difficult it is for individuals who know one language to learn the other language. According to Grimes and Grimes (1993), Japanese and Chinese are the two languages with the highest linguistic distance from English, followed by French and then Afrikaans, Norwegian and Swedish as the least distant from English. While the language distance between Chinese and Japanese is small, Chinese SMEs are more capable to break through the Japanese language barriers, however, their capability to break through the traditional western market is limited.

\section{Insert table 1 here.}

Mastering the foreign language becomes a precondition for Chinese SMEs' participation across national borders, as effective communications and shared cultural knowledge are essential to understanding international markets and behavior of global consumers. For most Chinese SMEs, the language barrier affects their capacity to interpret other cultures and thus enter other markets.

It is important to fully understand how a language is used by the people in the targeted foreign market at the technical level as well as at the cultural level. In this sense, language could be used as a promotion tool, at a lower level to build a bridge for technique understanding, or at a higher level a bridge for cultural understanding. As a promotion tool, Chinese SMEs use language to promote their own ideas, products or services to the stakeholders in other nations. Because of differences in values, thought processes, and language structure, it is not possible to meaningfully translate "word-for-word" from one language to another. Technical accuracy or perfect translation is not sufficient for Chinese SMEs to use the foreign languages for their business purpose, because many times communication cannot always be directly translated, and must certainly be conveyed in a more effective and comprehensive process. At a higher level of cultural understanding, they need to seek support from key stakeholders, such as global customers, media, regulators, foreign stockholders and suppliers in the global market for Chinese SME's perceptions, concepts, ideas, desires, attitudes to actions, and plans.

Moreover, language could be used as a defensive tool, at a lower level to build a bridge for technique understanding. The Chinese SMEs not only need to fully understand the legal meanings and the obligations behind the terms, condition, and agreement but also use the language without error to defend their interests in the global market. Once more, as a defensive tool at a higher level for cultural understanding, they need to defend their interests from competitors, regulators and other potential threats to express positions, attitudes, actions and procedures in accordance of the cultural background.

At this time, most Chinese SMEs are only at a very preliminary stage of using foreign languages as tool for business purposes. To be more competitive, they must move from a preliminary stage to a more advanced stage. Therefore, mastering the knowledge of language in a target market is essential for Chinese SMEs to fully participate and effectively compete in global markets.

\subsection{Culture}

The word culture originally comes from a Latin word that means of cultivation. There are many different definitions of culture. Kroeber and Kluckhohn (1952) compiled more than 200 different definitions of culture in their book. Most recently, UNESCO defined culture as the "set of distinctive spiritual, material, intellectual and emotional features of society or a social group which encompasses, in addition to art and literature, lifestyles, ways of living together, value systems, traditions and beliefs" (UNESCO, 2002). Culture can affect how a person takes certain actions and reacts to environmental changes (Ahlstrom and Bruton 2002). Generally, Chinese culture lacks the most important entrepreneurial values, such as creativity, innovation and flexibility. In addition, traditional Chinese values are in conflict with other certain key characteristics, such as a positive response to change, initiative and profit orientation (Kirby and Fan 1995). This attribute may constitute an internal barrier for Chinese SMEs to expand in the global market. Other culture related barriers include cultural differences, lack of communication, and different objectives which often lead to failure for many Sino-foreign cooperation projects (Lightfoot and Almeida 2007).

When a firm enters the foreign market, it must first understand the other culture (Ward and Rana-Deuba 1999) and then adapt their management style to fit with the local culture (Osland et al. 1999). The two parties need to 
build a bridge which is codified and transmitted formally through language (Nonaka, 1994). More importantly, they also need to build a tacit knowledge with which the two parties are able to achieve mutual understanding with informal communications.

\section{Insert table 2 here.}

From a business perspective, there are two critical components of culture for Chinese SMEs to consider when entering a foreign market. The first is market culture, which includes the commercial functions in transferring goods from producer to consumer, and the second is social culture, which refers to the beliefs and traditions within a particular society (pattern of customs, beliefs, and behaviors which are socially acquired and transmitted). The combination of market and social culture creates a unique business environment for each targeted "foreign" market, characterized by its own configuration of regulatory, administrative, policy and cultural dimensions.

From the Chinese SME's perspective, there are two ways to handle the challenges of foreign culture. The first way is to compromise Chinese culture and the SME's managerial culture to fit the local foreign culture. For example, at a market level, the Chinese SME needs to learn the foreign local culture, such as consumer's needs and wants, local ways of doing business, and then change their own administrative culture to be consistent with the local counterparts. In this way, Chinese SMEs tend to meet with less resistance from the foreign customers, regulators, media and other stakeholders. At social level, Chinese SMEs may need to change their Chinese culture to fit the targeted global market in terms of beliefs and traditions, pattern of customs, and behaviors. In the long term, this compromising strategy will allow the Chinese SME to gradually integrate into the foreign culture. The more advanced level of handling the challenges of foreign culture is to use an uncompromising strategy by making the other party adapt. For example, at a market level, the Chinese SME will bring their own administrative culture to the foreign market and make local employees, customers and regulators adopt the changes. At the social level, the Chinese SMEs will bring Chinese culture to the targeted foreign market with the objective of changing local culture. For a mature society with established culture, this uncompromising strategy will potentially receive resistance from foreign customers, regulators, media and other stakeholders.

Currently, most Chinese SMEs are not well prepared for cultural challenges when they enter the global market, due to their limited available resources, the complexity of foreign culture, and the differences between each market's regulatory systems and business environment. There is a need of contingency strategies to overcome the cultural constraints in the short run.

\subsection{Logistics}

Of the three constrains identified for this paper Insufficient knowledge of logistics is most likely the least daunting. If the language and markets are reasonably mastered, then the logistics is more of a practical matter. After a Chinese SME has developed sufficient skills in terms of foreign language and culture, the firm should focus more on the logistics.

Currently most Chinese SMEs lack the capital to pay all costs involved with export activities. Many of them also do not have direct access to foreign market due to their limited capability to handle the intimidating information of foreign market. Because of high risk in payment and shipment and delayed payments, many Chinese SMEs are reluctant to engage in logistics directly. Instead, they outsource the logistics functions to other firms in the supply chain. By doing so, they can avoid the potential risks involved in logistics, but also lose the opportunity to learn the foreign market, and they tend to be less capable to adjust to rapid changes in the global market. A complete global logistics system requires a firm to have a knowledge and practical experience with the required network of interconnected procedures/businesses involved in the global Marketing, which include not only the functions of marketing, contracting, global transportation, warehousing, distribution but also the potential legal and financial liabilities.

Currently, most Chinese SMEs outsource the logistics functions to other firms and treat logistics as a foreign transaction fee in which costs are added to domestic commerce. As an additional expenditure needed for marketing global products and services, this transaction fee makes the international sale different from the local sale, in which the international sales usually involve several more contracts to cover the required logistics. These contracts cover the transportation from SMEs' manufacturing factory to the foreign marketing via carriage by ocean, land or air under which goods are shipped. The contracts of insurance by which the goods are insured are also included. Various documents are needed such as the bill of lading, the marine insurance policy and the invoice.

The complexity of global logistics also depends on the transportation time and costs which are related to distance, regulations, and geography. Professionals with new skill sets and local knowledge are needed to represent different parties who can handle issues, such as lead times, required variability, variable productivity, quality assurance, tracking, performance measurement, problem resolution and risks reduction.

Due to the technical complexity of global logistics, most Chinese SMEs outsource their logistics function to other channel members without direct channel infrastructure. The consequence of the logistics system without direct channel infrastructure is that the Chinese SMEs are more controlled by channel captains, such as giant 
retailers. In long timer, they will have limited power to make own decisions and little potential growth.

\section{Insert table 3 here.}

For the other Chinese SMEs with a direct channel infrastructure to global market, they will be able to learn the global market and consequently make adjustment to the global changes. With more capabilities to make more autonomous decisions, these SMEs can gain more power from channel captains, such as retailers. With a high capability to price their product, these firms can achieve high potential growth.

\section{Building Blocks for Chinese SMEs to Access to Global Market}

Although most Chinese SMEs are still at the initial stage of participation in the global market, some have developed internal competencies that leverage various resources to overcome the language, culture and logistics constraints. By actively participating global markets, many Chinese SMEs can capture many new business opportunities, such as accessing new niche markets, exploiting economies of scale, developing broader marketing scope, etc. These SMEs can consequently upgrade their core competencies, such as improving their technological capability, developing innovative ways of reducing risks, lowering costs, leveraging R\&D for better products. In general, Chinese SMEs can have three primary venues as contingency strategy to enhance their core competencies that enable them to enter and participate within global markets. These contingency strategies include Niche markets, Strategic Networks, and E-commerce.

\subsection{Niche Market Strategy}

Niche Market Strategy is based upon the Chinese SME becoming the supplier of specialized niche products. By focusing on the niche market, the Chinese SME will become the supplier of specialized products. In this strategy the SME can overcome their limitation of language, culture and logistics by minimizing their usage of the language, limited access to the culture and reduced exposure to the logistics function. The SME can outsource their other marketing/operations functions to other business partners while they build their niche core competencies. This might be the easiest and least expensive route for those Chinese SMEs which have a strong desire to enter the global market but with only limited resources at currently time. Due to its passive nature, a niche strategy should only be used in a short term while the firm is building its core competence. In a long term, the firm should take more proactive approach to break the language, culture and logistics constraints.

By actively using the e-commerce, Chinese SMEs can acquire information of target customers and competitors, their values, behaviors and customs. Bypassing the constraints of language culture and logistics, the Chinese SMEs can significantly reduce search costs of the information and improve its operation efficiency across nations. E-commerce can also help Chinese SMEs to build its logistics system with the required network of interconnected procedures, such as marketing, contracting, global transportation, warehousing, distribution. Finally, e-commerce can also help Chinese SMEs to identify weakness of potential legal and financial liabilities and then fix the loopholes in an efficient manner.

\subsection{Strategic Networking}

Strategic networks can help Chinese SMEs to participate in the global markets by collaborating with other firms which help the Chinese SMEs to overcome the language, culture and logistics constraints. There are many benefits for Chinese SMEs to develop strategic network with foreign partners to resolve the language, culture and logistic barriers. The global experiences has demonstrated that strategic networking can provide tacit knowledge about international business practices (Eriksson et al. 1998; Sharma and Blomstermo, 2003; Haahti et al. 2005), which Chinese SMEs can learn the foreign market quickly.

Strategic networking can also help Chinese SMEs to access to foreign customers, suppliers, and other resources to success business transactions and operations (Zimmerman, Barsky and Brouthers 2009). It also can help Chinese SMES to learn the technology, business opportunities, capital and management skills (Zhou, Wu and Luo 2007). Finally, the strategic networking can help Chinese SMEs to develop competitive advantages through knowledge sharing, transferring and global business cooperation (Styles and Ambler, 1994). After the Chinese SMEs have developed their core competencies, they can later shift their focus from the market entry levels and develop skills and knowledge sets of language, culture and logistics.

Practically, a Chinese SME must understand three key elements when the firm starts develop its strategic networking with its foreign partners. These three key elements include relationship content, relationship governance and network structure (Hoang and Antoncic 2003). The relationship content includes elements flow through the network, such as information, resources, advice, and problem solving. In other words, the Chinese SMEs must set up a specific goal what elements are in shortage and the keys to open the foreign market. Second, in order to guarantee the competitive advantages, the Chinese SMEs must develop its relationship governance which includes not only the affective bonds, such as trust, the social mechanisms such as power, influence as well as the treat of ostracism. In addition, it must use written contracts to warrant the benefits. Finally, the Chinese SMEs must understand its own position within the network and setup objectives to upgrade its positions within the network in order to mobilize necessary resources to meet business objectives. 
At a preliminary stage of using strategic networking, the Chinese SMEs should focus on knowledge development and management skills about the global markets. At maturity stage, the Chinese SMEs should be the mastery of a foreign language, culture and logistics. It should have a relative strong position in its strategic network with more capability to expand its network size and scopes. In addition, it should be able to leverage market leadership for new relationships with other network clusters.

Overall, with increased market share and profits, the firms can continue upgrade their networks clusters either consolidating the network members or developing new relationships with the new network agents to support or facilitate additional functions. In this sense, by developing a dynamic strategic network, the firm can form alliances with different partners to overcome its language, culture and logistics constraints sequentially to access to the global markets. A dynamic strategic network allows Chinese SMEs to access to necessary resources that are beyond the reach of individual small enterprises while they develop their own specialization and concentrate on their core businesses.

\subsection{E-commerce}

The Chinese SMEs can leverage the internet resource to access to the global market. The internet on one hand can provide a platform that the Chinese SMEs can utilize to reduce the language, culture, and logistics constrains, it can also on the other hand provide a market mechanism that the Chinese SMEs can develop their the global market business strategy. By actively using the e-commerce, Chinese SMEs can acquire information of target customers and competitors, their values, behaviors and customs. Bypassing the constraints of language culture and logistics, the Chinese SMEs can significantly reduce search costs of the information and improve its operation efficiency across nations. E-commerce can also help Chinese SMEs to build its logistics system with the required network of interconnected procedures, such as marketing, contracting, global transportation, warehousing, distribution. Finally, e-commerce can also help Chinese SMEs to identify weakness of potential legal and financial liabilities and then fix the loopholes in an efficient manner.

Currently, Chinese SMEs have contributed significantly to both domestic market as well as global market via electronic commerce. Many of them acquire market information through e-commerce without incurring high costs. The e-commerce platform has helped the Chinese SMEs to overcome the constraints while improve their competitiveness in the global market. According to "2009 Annual Report on the development of Network enterprises" issued by Alibaba, after 10 years of development, network enterprises of China have gradually realized the integration with the mainstream of socio-economic system. By 2009, the amount of China's network enterprises has been expanded to 63 million, with the growing social impact (Zhao 2010). Thus, SMEs can make use of e-commerce to help enhance mutual exchanges and enter the market or expand the volume of foreign trade. The use of the internet to participate within e-commence may reduce the requirement for the Chinese SMEs in the language, culture, and logistics constraints. E-commerce logistics companies provide technical conditions and greatly leverage market environment, and for the logistics functions of integration and logistics enterprises to achieve economies of scale.

\section{Conclusion}

Globalization has created opportunities for Chinese SMEs to actively enter and participate in the global markets. Due to the nature of high competition, this opportunity has also created tremendous pressure on the Chinese SMEs to increase their capabilities to adapt to the market changes, innovative ways to develop the new market, and the entrepreneurial skills to meet global consumers' needs and wants. Three contingency strategies are proposed for the Chinese SMEs to overcome their language, culture and logistics constraints: niche market, strategic networking and e-commerce. These contingency strategies will be useful for the Chinese firms at an initial stage when they enter the global market, which will help them to compete effectively within Global markets while they focus on their core competence. As Chinese SMEs evolve, they need to master the use of language, culture, and logistics, which are the essential building blocks for their future success in global market. With these building blocks, these firms can expand their international participation and continually cultivate and improve their marketing prowess and competitive edge in the global market.

It is important to note that there are some weaknesses for our study in this project. First, our research paper is mainly a conceptual framework with a specific focus on the roles of langrage, culture and logistics for Chinese SMEs. While all Chinese SME faces difficulties in the above three areas when they enter the global market, they may face different challenges in the above three areas because they have different business focuses. For example, a Chinese SME in electronic manufacturing business may face more challenges in logistics, while another Chinese SME in movie business may face more challenges in language and culture. In the future, there is a need to uncover the patterns of these challenges for Chinese SMEs in the sectors. Second, most Chinese SMEs have their specific target global market, some of them are more focusing on North America, while others are focusing on Europe, South America, Africa or other countries. These markets at different geographic regions have different languages, cultures and logistic infrastructure, which constitute different barriers for Chinese SMEs. In the future, there is a need to discover the patterns of barriers across different geographic regions. There are many avenues which can be investigated in relation to the barriers Chinese SMEs face when they enter the global 
market. The more precise patterns related to each different factor should be based on empirical studies. This paper has hopefully provided an introduction to the area which can be empirically improved upon in the future.

\section{References}

Ahlstrom, D., \& Bruton, G. D. (2002). An institutional perspective on the role of culture in shaping strategic actions by technology-focused entrepreneurial firms in China. Entrepreneurship Theory and Practice, 26(4), 53-69.

Chen, H., \& Chen, T.-J. (1998). Network linkages and location choice in foreign direct investment. Journal of International Business Studies, 29 (3), 445-467.

Chen, J. (2006). Development of Chinese small and medium-sized enterprises. Journal of Small Business and Enterprise Development, 13 (2), 140-7.

Chiswick, B., \& Paul Miller. (2004). Linguistic Distance: A Quantitative Measure of Distance between English and Other Languages. IZA Discussion Paper, No. 1246.

Chung, C. (2006). Beyond guanxi: Network contingencies in Taiwanese business groups. Organization Studies, 27 (4): 461-489.

Du Toit, A. (2003). Knowledge: A sense making process shared through narrative. Journal of Knowledge Management, 7 (1), 27-37.

Eriksson, K., Hohenthal, J., \& Johanson, J. (1998). A model of learning in international business networks", in Albach, H., Dierkes, M., Berthoin Antal, A. and Vaillant, K. (Eds), Organisationslernen - institutionelle und kulturelle dimensionen, Sigma ed., Berlin, 337-53.

Grimes, J.E., \& B.F. Grimes. (1993). Ethnologue: Languages of the World. 13th ed. Dallas: Summer Institute of Linguistics.

Haahti, A., Madupu, V., Yavas, U., \& Babakus, E. (2005). Cooperative strategy, knowledge intensity and export performance of small and medium sized enterprises. Journal of World Business, 40 (2), 124-138.

Hoang, H., \& Antoncic, B. (2003). Network-Based Research in Entrepreneurship: A Critical Review. Journal of Business Venturing, 18 (2), 165-187.

Huang Xueli. (2009). Strategic decision making in Chinese SMEs. Chinese Management Studies, 3 (2), 87-101.

Hussain, J., Millman, C., \& Matlay, H. (2006). SME financing in the UK and in China: a comparative perspective. Journal of Small Business and Enterprise Development, 13 (4), 584-99.

Jones, M. V. (2001). First steps in internationalization: Concepts and evidence from a sample of small high-technology firms. Journal of International Management, 7 (3), 191-210.

Jutla, D., Bodorik, P., \& Dhaliwal, J. (2002). Government Support for the Readiness of Small and Medium Sized Enterprises. 35th Annual Hawaii International Conference on Systems Sciences, Hawaii.

Kirby, D., \& Fan, Y. (1995). Chinese cultural values and entrepreneurship: a preliminary consideration. Journal of Enterprising Culture, 3 (3), 245-60.

Kroeber, A. L., and C. Kluckhohn. (1952). Culture: A critical review of concepts and definitions. Peabody Museum. Cambridge, Massachusetts, United States.

Lee, C., Lee, K., \& Pennings, J. M. (2001). Internal capabilities, external networks, and performance: A study on technology-based ventures. Strategic Management Journal, 22 (6/7): 615-640.

Li Jun., \& Matlay, H. (2006). Chinese entrepreneurship and small business development: an overview and research agenda. Journal of Small Business and Enterprise Development, 13 (2), 248-262.

Lightfoot, W.S., \& Almeida, J. (2007). Leveraging knowledge in China: the experience of a foreign entrepreneur. Journal of Technology Management in China, 2 (2) 177- 188.

Ma. Evelina., Ascalon, Deidra., J. Schleicher., \& Marise Ph. Born. (2008). Cross-cultural social intelligence; an assessment for employees working in cross-national contexts. Cross Cultural Management, 15 (2), 109-130.

MacGregor R C. (2004). Factors associated with formal networking in regional small business: some findings from a study of Swedish SMEs. Journal of Small Business and Enterprise Development, 11 (1), 60-74.

Mu Jifeng., Gang Peng., \& Yi Tan. (2007). New product development in Chinese SMEs; Key success factors from a managerial perspective. International Journal of Emerging Markets, 2 (2), 123-143.

Nonaka, I. (1994). Dynamic Theory of Organizational Knowledge Creation. Organization Science, 5(1) 14-37.

Okura Masanori. (2008). Firm Characteristics and Access to Bank Loans: An Empirical Analysis of Manufacturing SMEs in China. International Journal of Business and Management Science, 1 (2), 165-187.

Osland, J.S., De Franco, S., \& Osland, A. (1999). Organizational implications of Latin American culture: Lessons for the expatriate manager. Journal of Management Inquiry, 8 (2), 1-29.

Ren, J. (2003). The application of analysis hierarchy process on the SMEs' competitiveness evaluation. Systems 
Engineering-Theory \& Practice, 3, 91-95.

Sharma, D. D., \& Blomstermo, A. (2003). The internationalization process of born globals: A network view. International Business Review, 12 (6) 739-754.

Singh Rajesh K., Suresh K. Garg, S., \& G. Deshmukh. (2010). The competitiveness of SMEs in a globalized economy; Observations from China and India. Management Research Review, 33 (1), 54-65.

Styles, C., \& Ambler, T. (1994). Successful export practice: The UK experience. International Marketing Review, $11(6), 23-47$.

UNESCO. (2002). Universal Declaration on Cultural Diversity, issued on International Mother Language Day, February 21, 2002. [Online] Available: www.unesco.org/education/imld_2002/unversal_decla.shtml

Ward, C., \& Rana-Deuba, A. (1999). Acculturation and adaptation revisited. Journal of Cross-Cultural Psychology, 30, 422-442.

Wright, M., Westhead, P., \& Ucbasaran, D. (2007). Internationalization of SMEs and international entrepreneurship: A critique and policy implications. Regional Studies, 41 (7): 1013-1030.

Zhang, H J., \& Hang, B.C. (2007). Study on comprehensive assessment system of sustainable development for growth SMEs'. Studies in International Technology and Economy, 10 (3), 37-41.

Zhao Yanan. (2010). Research on the Approaches of the participation of China's SMEs in International Trade under Financial Crisis. International Journal of Business and Management, 5 (1), 69-73.

Zhou Lianxi., Wei-ping Wu., \& Xueming Luo. (2007). Internationalization and the performance of born-global SMEs: the mediating role of social networks. Journal of International Business Studies, 38 (4) 673-91.

Zimmerman, Monica., A, Barsky., David, Brouthers., \& Keith D. (2009). Networks, SMEs, and International Diversification. Multinational Business Review, 17 (4) 143-162.

Table 1. The Roles of Language for Chinese SMEs in Global Market

\begin{tabular}{|l|l|l|}
\hline & \multicolumn{1}{|c|}{$\begin{array}{c}\text { As a bridge for technique } \\
\text { understanding }\end{array}$} & As a bridge for cultural understanding \\
\hline $\begin{array}{l}\text { As a } \\
\text { promotional } \\
\text { tool }\end{array}$ & $\begin{array}{l}\text { Correctly use the language to } \\
\text { interpret the perceptions, concepts, } \\
\text { ideas, desires, attitudes expressed by } \\
\text { the key stakeholders, such as global } \\
\text { customers, media, regulators, foreign } \\
\text { stockholders and suppliers in the } \\
\text { global market. }\end{array}$ & $\begin{array}{l}\text { To seek full support from key } \\
\text { stakeholders, such as global customers, } \\
\text { media, regulators, foreign stockholders } \\
\text { and suppliers in the global market for } \\
\text { Chinese SME's perceptions, concepts, } \\
\text { ideas, desires, attitudes to actions, and } \\
\text { plans. }\end{array}$ \\
\hline $\begin{array}{l}\text { As a } \\
\text { defensive tool }\end{array}$ & $\begin{array}{l}\text { Fully understand the legal meanings } \\
\text { and the obligations behind terms, } \\
\text { conditions, and agreements and use } \\
\text { the language without technique errors } \\
\text { to defend Chinese SME's interests in } \\
\text { the global market. }\end{array}$ & $\begin{array}{l}\text { Defend Chinese SME's interests from } \\
\text { competitors, regulators and other } \\
\text { potential threats to express positions, } \\
\text { attitudes, actions and procedures in } \\
\text { accordance of the cultural background. }\end{array}$ \\
\hline
\end{tabular}

Table 2. The Roles of Culture for Chinese SMEs in Global Market

\begin{tabular}{|l|l|l|}
\hline $\begin{array}{l}\text { Compromise own } \\
\text { culture to fit the local } \\
\text { culture }\end{array}$ & $\begin{array}{l}\text { Change Chinese SMEs own } \\
\text { administrative culture to fit for the global } \\
\text { market. } \\
\text { Less resistance from foreign customers, } \\
\text { regulators, media and other stakeholders. }\end{array}$ & $\begin{array}{l}\text { Change Chinese culture to fit the } \\
\text { targeted global market in terms of } \\
\text { beliefs and traditions, pattern of } \\
\text { customs, and behaviors which are } \\
\text { socially acquired and socially } \\
\text { transmitted. }\end{array}$ \\
\hline $\begin{array}{l}\text { Stand - make the } \\
\text { other change }\end{array}$ & $\begin{array}{l}\text { Bring Chinese SMEs' own administrative } \\
\text { culture to the global market. } \\
\text { Potential resistance from foreign } \\
\text { customers, regulators, media and other } \\
\text { stakeholders. }\end{array}$ & $\begin{array}{l}\text { Bring Chinese culture to the targeted } \\
\text { global market without the changes } \\
\text { of beliefs and traditions, pattern of } \\
\text { customs, and behaviors which are } \\
\text { socially acquired and socially } \\
\text { transmitted. }\end{array}$ \\
\hline
\end{tabular}


Table 3. The Roles of Channel Infrastructure for Chinese SMEs in Global Market

\begin{tabular}{|l|l|l|l|}
\hline & \multicolumn{2}{|c|}{$\begin{array}{c}\text { Weak Autonomous Decision by } \\
\text { Chinese SMEs }\end{array}$} & $\begin{array}{l}\text { Strong Autonomous Decision by } \\
\text { Chinese SMEs }\end{array}$ \\
\hline $\begin{array}{l}\text { Without Direct } \\
\text { Mannel to Global }\end{array}$ & $\bullet \quad \begin{array}{l}\text { More controlled by giant retailers } \\
\text { Market }\end{array}$ & $\begin{array}{l}\text { Limited power to make own } \\
\text { decisions } \\
\text { Little potential growth }\end{array}$ & $\begin{array}{l}\text { Gradually lose the power of } \\
\text { autonomous decision due to the } \\
\text { channel power of retailers and } \\
\text { other mid-men in the marketplace. }\end{array}$ \\
\hline $\begin{array}{l}\text { With Direct Channel } \\
\text { to Global Market }\end{array}$ & $\begin{array}{l}\text { Able to understand the global } \\
\text { market }\end{array}$ & $\begin{array}{l}\text { Mbre power shifted from retailer } \\
\text { global changes adjustment to the } \\
\text { Move the direction to make more } \\
\text { autonomous decisions }\end{array}$ & $\begin{array}{l}\text { More capable to make own } \\
\text { decisions in terms of pricing and } \\
\text { promotion } \\
\text { High potential growth }\end{array}$ \\
\hline
\end{tabular}

Table 4. Building Blocks for Chinese SMEs to Access to Global Market

\begin{tabular}{|c|c|c|c|}
\hline Constraints & $\begin{array}{l}\text { Niche Market } \\
\text { Strategy }\end{array}$ & Strategic Networking & E-commerce: \\
\hline Language & $\begin{array}{l}\text { - Minimize the usage } \\
\text { of language }\end{array}$ & $\begin{array}{l}\text { - Knowledge } \\
\text { accumulation } \\
\text { learning }\end{array}$ & $\begin{array}{l}\text { - acquire information of } \\
\text { target customers and } \\
\text { competitors, their values, } \\
\text { behaviors and customs }\end{array}$ \\
\hline Culture & $\begin{array}{l}\text { - Minimize the access } \\
\text { of foreign culture }\end{array}$ & $\begin{array}{l}\text { - Skill development for } \\
\text { the management }\end{array}$ & $\begin{array}{l}\text { - Learning, adapting and } \\
\text { changing foreign culture }\end{array}$ \\
\hline Logistics & $\begin{array}{l}\text { - Minimize the usage } \\
\text { of logistics }\end{array}$ & $\begin{array}{l}\text { - Learning, developing } \\
\text { and outsourcing }\end{array}$ & $\begin{array}{l}\text { - Building logistics system } \\
\text { with the required network } \\
\text { of } \\
\text { procedures }\end{array}$ \\
\hline $\begin{array}{l}\text { Overall } \\
\text { strategy }\end{array}$ & $\begin{array}{l}- \text { Passive format to } \\
\text { handle } \\
\text { constraints }\end{array}$ & $\begin{array}{ll}- & \text { Preliminary stage } \\
\text { focusing on learning } \\
\text { - } \\
\text { Maturity stage focusing } \\
\text { on core competence } \\
\text { development }\end{array}$ & $\begin{array}{l}\text { - Proactive to participate the } \\
\text { global demand chain } \\
\text { system }\end{array}$ \\
\hline
\end{tabular}

